\title{
Peran Rumput Vetiver (Chrysopogon zizanioides) dalam Fitoremediasi Pencemaran Perairan Sungai

\author{
Role of Vetiver Grass (Chrysopogon zizanioides)
} in Phytoremediation of Contaminated River Waters
}

\author{
Wage Komarawidjaja dan Yudhi Soetrisno Garno \\ Pusat Teknologi Lingkungan - BPPT \\ Gedung Geostech 820, Puspiptek Serpong 15314, Indonesia \\ Email : wage.komarawidjaja@bppt.go.id
}

\begin{abstract}
In order to recover the water quality of river, vetiver (Chrysopogon zizanioides) grasses were planted along the river bank of Cikapundung river for 63 days. Two (2) boxes were developed and flowed with river water and ground water respectively. Biomass productions were measured, in respect to the length of the tiller and the root of vetiver. In general, the tillers and roots that are planted in the media, which was flowed with river water, showed better performance (longer) than the tillers and roots that are planted in the media, which was flowed with ground water. Based on the dry weight measurements, it was observed that the growth of roots were faster than the growth of tillers until the 3rd sampling period. Those data show that Vetiver has a good ability in utilisation of organic waste from the Cikapundung river waters as their nutrient sources. Thus, utilisation of vetiver as candidate plant for phytoremediation activity along the Cikapundung River Bank is proposed. At the other side, compare to the tiller growth, faster growth of the vetiver's root can be utilized as anti-slide plant along the river bank.
\end{abstract}

Keywords : Vetiver (Chrysopogon zizanioides), phytoremediation, Cikapundung river

\begin{abstract}
ABSTRAK
Dalam rangka memperbaiki kualitas perairan Sungai, vetiver (Chrysopogon zizanioides) telah ditanam pada kawasan bantaran Sungai Clkapundung selama 63 hari. Dua wadah dialiri dengan sumber air yang berbeda, yaitu air sungai dan air tanah (sumur). Produksi biomassa diukur setiap 20 harian sekali, dengan fokus pengukuran pada pertumbuhan tunas dan akar vetiver. Secara umum, pertumbuhan tunas dan akar vetiver yang ditanam pada wadah yang dialiri air sungai tumbuh lebih baik (panjang) daripada vetiver yang ditanam pada wadah yang dialiri air tanah. Data pengukuran berat kering biomassa menunjukkan bahwa hingga waktu ketiga pengambilan contoh, perpanjangan akar lebih cepat daripada perpanjangan tunas. Data-data tersebut menunjukkan bahwa vetiver memiliki kemampuan yang sangat baik dalam memanfaatkan nutrien yang berasal dari limbah organik Sungai Cikapundung. Oleh karena itu, vetiver dapat diusulkan sebagai tanaman untuk aktivitas fitoremediasi di kawasan bantaran Sungai Cikapundung. Pertambahan panjang akar vetiver yang lebih cepat daripada pertambahan panjang tunasnya juga dapat dimanfaatkan sebagai tanaman anti longsor di sepanjang kawasan bantaran sungai.
\end{abstract}

Kata kunci: Vetiver (Chrysopogon zizanioides), fitoremediasi, Sungai Cikapundung

\section{PENDAHULUAN}

Sungai Cikapundung merupakan bagian dari kawasan Daerah Aliran Sungai (DAS) Citarum dan menjadi salah satu sumber air baku bagi beberapa kegiatan masyarakat maupun industri di sekitarnya, seperti untuk Pembangkit Listrik Tenaga Air (PLTA), irigasi pertanian, air minum (PDAM) dan bahkan sebagai tempat pembuangan limbah domestik bagi penduduk di sekitarnya ${ }^{(1)}$.
Dampak dari pembuangan limbah ke Sungai Cikapundung adalah pencemaran perairan, yang ditandai dengan menurunnya kualitas air sungai tersebut. Berdasarkan hasil uji kualitas air terhadap anak-anak Sungai Citarum yang dihitung dengan metode Storet terhadap 100 titik pada tahun $2007^{(2)}$ diketahui bahwa Sungai Cikapundung termasuk dalam kategori kualitas terburuk (nilai Storet $<100$ ), dimana parameterparamter Oksigen terlarut (DO), Biologically Oxygen Demand (BOD), Chemically Oxygen 
Demand (COD), ammonia, sulfida dan total Coli menunjukkan nilai diatas baku mutu yang telah ditetapkan. Hal ini mengindikasikan bahwa pencemaran yang terjadi berasal dari limbah domestik maupun limbah organik lainnya. Sementara itu, beberapa alternatif teknologi telah banyak digunakan untuk menanggulangi pencemaran dari limbah-limbah tersebut dan salah satunya adalah teknologi fitoremediasi.

Fitoremediasi adalah suatu teknologi yang menggunakan tanaman sedemikian rupa untuk melalukan proses menghilangkan kontaminan baik polutan organik maupun logam berat, hara tanaman dan mineral lainnya sehingga tidak berbahaya bagi lingkungan.

Tahapan proses penghilangan polutan melalui teknologi fitoremediasi adalah sebagai berikut (Gambar 1):

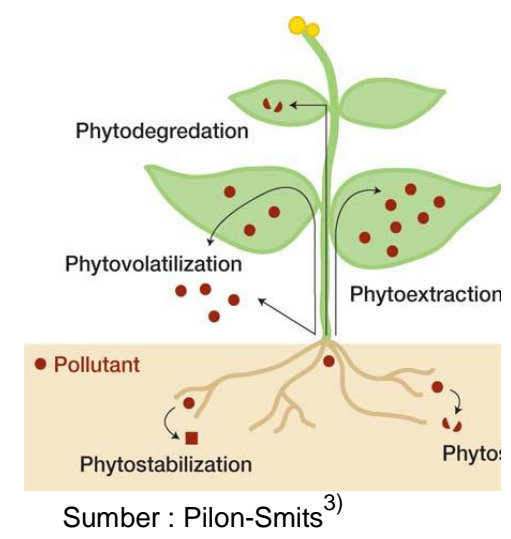

Gambar 1. Proses Fitoremediasi Kontaminan pada Tanaman

1. Fitodegradasi yaitu suatu proses dimana tanaman yang berasosiasi dengan mikroorganisme perairan dan/atau tanah melalukan biodegradasi polutan organik.

2. Fitoekstraksi yaitu suatu proses dimana tanaman melakukan penumpukan (konsentrasi) dan akumulasi polutan/ kontaminan didalam jaringan tanaman.

3. Fitostabilisasi yaitu suatu proses dimana tanaman melakukan imobilisasi kontaminan/polutan logam dalam zona perakaran, dan

4. Fitovolatilisasi yaitu suatu proses dimana tanaman melalukan serapan kontaminan didalam jaringan tanaman diatas permukaan tanah dan kemudian melalukan transformasi menjadi senyawa yang dapat menguap ke atmosfir.

Vetiver (Chrysopogon Zizanoides) (Gambar 2) merupakan salah satu tumbuhan yang dapat dimanfaatkan dalam teknologi fitoremediasi karena memiliki kemampuan yang sangat baik dalam menyerap polutan. Kemampuan vetiver dalam menyerap nutrien, khususnya nitrogen $(\mathrm{N})$ dan fosfat $(\mathrm{P})$ telah teruji dengan baik.

Menurut Zeng et.al. purifikasi air sungai dengan memanfaatkan vetiver, mampu mengurangi konsentrasi $P$ hingga $98 \%$ setelah 3-4 minggu serta $71-74 \% \mathrm{~N}$ dalam $4-5$ minggu waktu penelitian ${ }^{(4)}$. Kemampuan vetiver dalam menyerap nutrien juga dilengkapi dengan kemampuannya dalam menurunkan konsentrasi bakteri coli pada suatu badan perairan yang tercemar. Ujicoba penanaman vetiver pada kolam limbah dan kawasan lahan basah menunjukkan penurunan konsentrasi bakteri coli dari $60-800 / 100 \mathrm{ml}$ menjadi $13-580 / 100 \mathrm{ml}^{(5)}$.

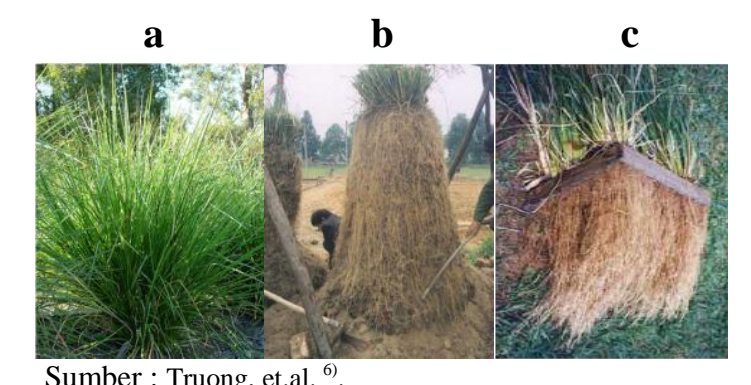

Gambar 2. Rumpun dan Perakaran Tanaman Vetiver media Tanah $(a, b)$ serta Media Air (c)

Kemampuan vetifer yang tinggi dalam menyerap nutrien juga ditunjang oleh karakteristik morofologi serta fisiologinya yang sangat mendukung sebagai organisma pengolah limbah ${ }^{(6,7,8)}$, antara lain:

1. Batangnya yang tegak dan kaku sehingga sangat kuat dalam menahan aliran air yang cukup deras.

2. Tubuhnya tebal serta memiliki pori yang berfungsi sebagai filter untuk sedimen yang halus maupun yang kasar.

3. Sistem penetrasi akar yang dalam dan ekstensif sehingga dapat menahan buangan air.

4. Toleransi yang tinggi terhadap pencemar logam berat, seperti Arsen, Kadmium, Tembaga, Krom, Nikel, Selenium dan Seng.

5. Toleransi yang tinggi terhadap kondisi lingkungan yang kurang baik, seperti kadar keasaman tanah, alkalinitas serta salinitas tinggi dan toksisitas Alumunium serta Mangan.

Berdasarkan informasi tersebut, bahwa pemanfaatan vetiver sebagai penyerap 
pencemar organik akan mampu mengurangi pencemaran lingkungan. Oleh karena itu, dengan karakteristik yang dimiliki rumput vetiver, penelitian ini dimaksudkan untuk menelaah kemampuannya dalam memanfaatkan nutrisi yang berasal dari air sungai yang tercemar.

\section{BAHAN DAN METODE}

Untuk mengetahui kemampuan vetiver dalam memanfaatkan nutrien yang berasal dari air sungai Cikapundung, maka vetiver ditanam pada media yang diasumsikan sangat sedikit kandungan nutriennya, yaitu pasir. Media pertumbuhan dibedakan menjadi media yang dialiri air sungai Cikapundung dan media yang dialiri dengan air tanah. Suplai air (nutrien) dilakukan secara terus menerus agar ketersediaan nutrien selalu berlebih.

\subsection{Lokasi, Waktu dan Wadah Penelitian}

Penelitian ini dilaksanakan di salah satu bantaran Sungai Cikapundung yang termasuk wilayah administrasi Kelurahan Balubur, Kecamatan Tamansari, Kota Bandung. Dilaksanakan dalam waktu 63 hari, bulan Juli sampai dengan September 2012.

Wadah penelitian terdiri dari 2 bak beton dengan ukuran masing-masing bak adalah $10 \mathrm{x}$ $1 \times 1 \mathrm{~m} 2$ (Gambar 3). Bak kesatu dialiri dengan air yang berasal dari Sungai Cikapundung yang subur sedangkan bak kedua dialiri dengan air tanah dari sumur penduduk yang rendah nutrien. Air diberikan sebanyak 2 kali sehari pagi dan sore masing-masing sebanyak 500 Liter. Konsentrasi nutrien pada air tanah maupun air sungai dianalisis di laboratorium. meliputi panjang akar dan panjang tunas (yang diukur langsung di lapangan) serta berat kering akar dan berat kering tunas diukur di laboratorium.

Pengambilan contoh biomassa vetiver yang berasal dari 3 tanaman vetiver dari masingmasing bak penelitian (air sungai maupun air tanah). Hasil pengukuran kemudian dirataratakan. Sedangkan jaringan tanaman yang dianalisa dalam penelitian ini adalah total tanaman yang dibagi menjadi akarnya saja (below ground mass) dan daunnya saja (above ground mass). Unsur-unsur yang dianalisa adalah unsur $\mathrm{N}, \mathrm{P}$, dan $\mathrm{C}$-organik.

\section{HASIL DAN PEMBAHASAN}

\subsection{Kondisi Nutrien Air Tanah dan Air Sungai}

Hasil pengukuran terhadap konsentrasi nutrien pada air tanah maupun air sungai adalah sebagai berikut (Tabel 1):

Tabel 1. Hasil Pengukuran Konsentrasi Nutrien pada Air Tanah dan Air Sungai Cikapundung

\begin{tabular}{c|c|c|c|c}
\hline $\begin{array}{c}\text { Sumber } \\
\text { Nutrien }\end{array}$ & $\mathbf{p H}$ & $\mathbf{N}(\mathbf{m g} / \mathbf{l})$ & $\mathbf{P}(\mathbf{m g} / \mathbf{l})$ & $\mathbf{C}(\mathbf{m g} / \mathbf{l})$ \\
\hline Air Tanah & 7,15 & 1,06 & 0,47 & $<0,1$ \\
\hline Air Sungai & 6,87 & 2,4 & 0,4 & 5,03 \\
\hline
\end{tabular}

Hasil analisis kandungan nutrien pada kedua sumber air yang digunakan pada penelitian ini menunjukkan bahwa $\mathrm{pH}$ kedua sumber air

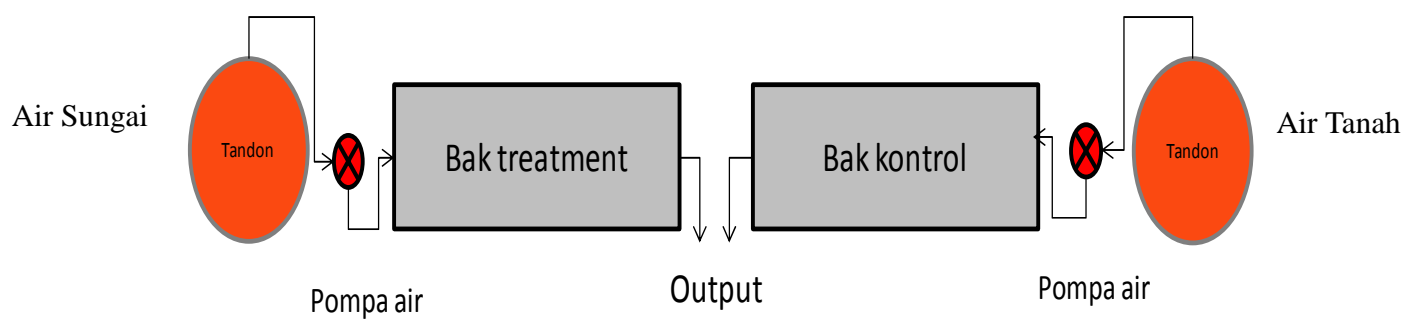

Gambar 3. Disain Wadah Penelitian

\subsection{Pengambilan Contoh}

Pengambilan contoh biomassa selama rentang waktu penelitian telah dilakukan sebanyak 4 kali, yaitu pada tanggal 5 Juli 2012 (t-0), 26 Juli 2012 (t-1), 16 Agustus 2012 (t-2) dan 6 September 2012 (t-4). Data yang diukur berada pada kisaran nilai $\mathrm{pH}$ normal, kandungan total $\mathrm{N}$ dan total karbon (C) pada air sungai menunjukkan nilai yang lebih tinggi daripada air tanah, sedangkan konsentrasi total $P$ pada kedua sumber air menunjukkan nilai yang hampir sama. Pengukuran sesaat tersebut sebenarnya belum dapat mereprentasikan kualitas air secara utuh, namun secara umum 
konsentrasi $P(0,4-0,47 \mathrm{mg} / \mathrm{l})$ pada air tanah maupun air sungai termasuk dalam klasifikasi mutu air kelas III (batas nilai P: 0,2 mg/l). yaitu air yang peruntukannya dapat digunakan untuk budidaya (ikan,peternakan), air pengairan dan atau peruntukan lain yang mempersyaratkan mutu air yang sama dengan kegunaan tersebut.

Sedangkan konsentrasi N (1,06-2,4 mg/l) masih termasuk dalam klasifikasi mutu air kelas I (batas nilai $\mathrm{N}$ : $10 \mathrm{mg} / \mathrm{l}$ ), yaitu air yang peruntukannya dapat digunakan untuk air baku air minum ${ }^{(9,10)}$.

Meskipun secara umum kondisi nutrien menunjukkan hasil yang masih cukup baik, namun kandungan $\mathrm{N}$ dan $\mathrm{C}$ pada air sungai menunjukan konsentrasi yang lebih tinggi, yang ditunjukan oleh konsentrasi $\mathrm{N}$ air sungai dua kali lipat $\mathrm{N}$ air tanah dan konsentrasi $\mathrm{C}$ air sungai 50 kali lebih tinggi dibandingkan dengan $\mathrm{C}$ air tanah (Tabel 1). Ini mengindikasikan bahwa air sungai Cikapundung lebih subur dibandingkan dengan air tanah. Kondisi ini diduga kuat terkait dengan imbuhan limbah organik dari kegiatan domestik, pertanian dan peternakan dari hulu sungai tersebut.

\subsection{Analisis terhadap Pertumbuhan Biomassa dan Jaringan Tanaman}

\subsubsection{Pertumbuhan Tunas}

Berdasarkan hasil 4 kali pengambilan sampel, yaitu pada hari ke-0, 21, 41 dan 63 diketahui rata-rata panjang tunas (above ground mass) antara vetiver yang tumbuh pada media dengan nutrisi air sungai lebih panjang dari pada vetiver yang tumbuh pada media dengan sumber nutrisi dari air tanah (Gambar 4).

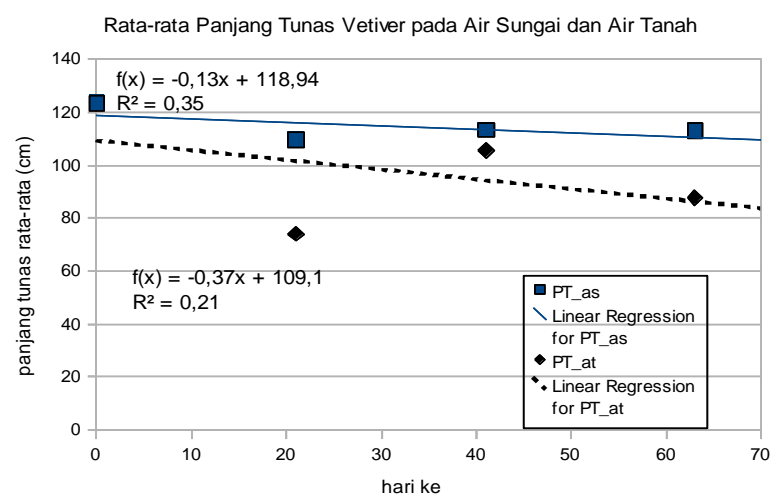

Gambar 4. Rata-rata Panjang Tunas Vetiver pada Media Air Sungai dan Air Tanah
Namun panjang tunas akhir pada kedua perlakuan menunjukkan pola menurun jika dibandingkan antara hari ke-0 hingga hari ke-63. Sebaliknya hasil penghitungan pertambahan biomassa tunas (Tabel 2), biomasa tunas vetiver dengan media air sungai, pada hari ke 63 pengamatan, mengalami kecenderungan naik hampir 3 kali lipat $(2,97 x)$ dibandingkan berat biomassa pada hari ke 0 , sedangkan untuk vetiver dengan media air tanah mengalami penurunan 0,82 kali lipat.

Berdasarkan data biomasa tersebut, rumput vetiver dengan media tanam air sungai menghasilkan pertambahan biomasa lebih tinggi dibanding dengan biomasa yang dihasilkan rumput vetiver dengan media air tanah. Data pengamatan menunjukkan bahwa kemungkinan besar tunas vetiver tidak lagi bertambah panjang namun bertambah besar karena biomassanya (hasil pengukuran berat kering) tetap meningkat dalam 63 hari pengamatan.

Hasil penelitian lain yang dilakukan menggunakan beberapa jenis rumput-rumputan, diketahui bahwa vetiver adalah rumput yang paling tahan terhadap kondisi kekeringan (11). Hal ini juga dapat mendukung dugaan adanya kemampuan vetiver untuk tetap tumbuh pada musim kemarau panjang dengan cara mengurangi kadar air di dalam tubuhnya, sehingga berat basahnya berkurang meskipun berat keringnya meningkat.

\subsubsection{Pertumbuhan Akar}

Pertumbuhan akar vetiver pada kedua perlakuan menunjukkan hasil yang berlawanan (Tabel 3), dimana panjang akar vetiver pada media tumbuh air sungai menunjukkan hasil yang meningkat sejak hari antara hari ke-21 (26 $\mathrm{cm}$ ) hingga ke-63 menjadi $42 \mathrm{~cm}$, sebaliknya untuk rumput vetiver pada media air sumur, panjang akar hanya berubah sedikit pada hari ke-21 $(26,67 \mathrm{~cm})$ menjadi $28,67 \mathrm{~cm}$ pada hari ke-63.

Pertumbuhan akar pada media dengan sumber nutrisi dari air sungai juga lebih tinggi daripada pertumbuhan akar pada media dengan sumber nutrisi dari air tanah.

Tabel 2. Hasil Pengukuran Panjang dan Berat Kering Tunas Vetiver

\begin{tabular}{c|c|c|c|c}
\hline $\begin{array}{c}\text { Wkt } \\
\begin{array}{c}\text { Pengamatan } \\
\text { (hari ke) }\end{array}\end{array}$ & $\begin{array}{c}\text { Pjg Tunas (AS) } \\
(\mathrm{cm})\end{array}$ & $\begin{array}{c}\text { Pjg Tunas (AT) } \\
(\mathrm{cm})\end{array}$ & $\begin{array}{c}\text { Berat Kering Tunas (AS) } \\
(\mathrm{gr})\end{array}$ & $\begin{array}{c}\text { Berat Kering Tunas (AT) } \\
(\mathrm{gr})\end{array}$ \\
\hline 0 & 123,3 & 123,3 & $7,55(1 \mathrm{x})$ & $7,55(1 \mathrm{x})$ \\
\hline 21 & 109,67 & 74,00 & $9,00(1,2 \mathrm{x})$ & $3,17(0,42 \mathrm{x})$ \\
\hline 41 & 113,50 & 105,67 & $10,10(1,34 \mathrm{x})$ & $4,70(0,62 \mathrm{x})$ \\
\hline 63 & 113,00 & 87,67 & $21,70(2,9 \mathrm{x})$ & $6,20(0,82 \mathrm{x})$ \\
\hline
\end{tabular}


Tabel 3. Hasil Pengukuran Panjang dan Berat Kering Akar Vetiver

\begin{tabular}{c|c|c|c|c}
\hline $\begin{array}{c}\text { Wkt } \\
\begin{array}{c}\text { Pengamatan } \\
\text { (hari ke) }\end{array}\end{array}$ & $\begin{array}{c}\text { Pjg Akar } \\
(\text { AS) }(\mathrm{cm})\end{array}$ & $\begin{array}{c}\text { Pjg Akar (AT) } \\
(\mathrm{cm})\end{array}$ & $\begin{array}{c}\text { Berat Kering Akar } \\
(\mathrm{AS})(\mathrm{gr})\end{array}$ & $\begin{array}{c}\text { Berat Kering Akar } \\
\text { (AT) }(\mathrm{gr})\end{array}$ \\
\hline 0 & 25,00 & 25,00 & $9,62(1 \mathrm{x})$ & $9,62(1 \mathrm{x})$ \\
\hline 21 & 26,00 & 26,67 & $27,80(2,89 \mathrm{x})$ & $9,70(1,01 \mathrm{x})$ \\
\hline 41 & 34,67 & 27,67 & $10,50(1,09 \mathrm{x})$ & $6,10(0,63 \mathrm{x})$ \\
\hline 63 & 42,00 & 28,67 & $18,13(1,89 \mathrm{x})$ & $7,73(0,80 \mathrm{x})$ \\
\hline
\end{tabular}

Hal ini juga didukung oleh nilai prosentase pertambahan biomasa akar (Tabel 3) dan rasio berat kering panjang tunas dan panjang akar (Tabel 4), dimana pertumbuhan biomassa akar pada air sungai dua kai lipat $(1,89 x)$ biomasa hari ke-0 dan vetiver dengan media air tanah stagnan bahkan berkurang $(0,80 x)$ dari total biomasa hari ke- 0 .

Berdasarkan hasil pengolahan data diatas, diketahui bahwa dalam rentang waktu sekitar 2 bulan (63 hari), pertumbuhan akar menunjukkan hasil yang lebih cepat daripada pertumbuhan panjang tunas. Meskipun beberapa literatur menyebutkan bahwa bagian daun vetiver dapat mencapai ketinggian 1,2-1,5 m.

Namun secara umum, vetiver yang ditanam pada media yang diberi air sungai menunjukkan pertumbuhan yang lebih baik daripada vetiver yang ditanam pada media yang diberi air tanah.

Tabel 4. Rasio Berat Kering Panjang Tunas dengan Panjang Akar

\begin{tabular}{c|c|c}
\hline $\begin{array}{c}\text { Waktu } \\
\text { pengamatan } \\
\text { (hari ke-) }\end{array}$ & $\begin{array}{c}\text { Rasio Berat } \\
\text { Kering } \\
\text { Tunas/Akar (AS) }\end{array}$ & $\begin{array}{c}\text { Rasio Berat } \\
\text { Kering } \\
\text { Tunas/Akar (AT) }\end{array}$ \\
\hline 0 & 0,78 & 0,78 \\
\hline 21 & 0,32 & 0,33 \\
\hline 41 & 0,96 & 0,77 \\
\hline 63 & 1,2 & 0,8 \\
\hline
\end{tabular}

Namun diduga bahwa dalam rentang waktu sekitar 2 bulan pada penelitian ini, karakteristik pola pertumbuhan vetiver adalah dengan memperpanjang akar terlebih dahulu sebelum menambah panjang tunas. Hal ini kemungkinan besar adalah salah satu mekanisme vetiver dalam beradaptasi mengumpulkan atau mencari sumber nutrien dari dalam tanah pada fase-fase awal kehidupannya.

\subsubsection{Fitoremediasi Unsur Kontaminan Air Sungai}

Fitoremediasi sebagaimana diungkapkan pada bagian pendahuluan, adalah merupakan suatu teknologi pemanfaatan tanaman sedemikian rupa untuk melalukan proses menghilangkan kontaminan baik polutan organik dan an-organik maupun logam berat, hara tanaman yang berlebih dan mineral lainnya sehingga tidak berbahaya bagi lingkungan.

Dengan mengintroduksi budidaya rumput vetiver, diharapkan mampu menyerap unsur pencemaran air sungai antara lain unsur $\mathrm{N}, \mathrm{P}$ dan C. Dari hasil analisis jaringan tanaman vetiver, menunjukkan bahwa jumlah nitrogen yang diserap oleh tanaman di dalam kolam/bak air tanah (Gambar 5) pada mulanya adalah sebesar $91,36 \mathrm{mg}(1,21 \%$ dari berat kering 7,55 gram) dan setelah 63 hari adalah sebesar 63,89 $\mathrm{mg}(1,03 \%$ dari berat kering 6,2 gram).

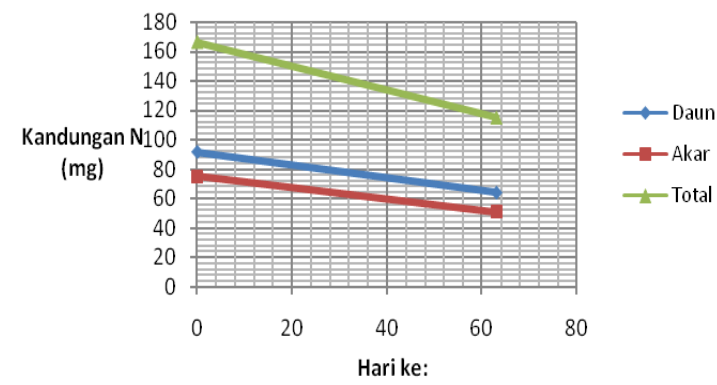

Gambar 5. Kandungan N pada Daun dan Akar Vetiver di Air Tanah

Sedangkan hasil analisis jaringan tanaman vetiver yang tumbuh pada media air sungai (Gambar 6) menunjukkan bahwa jumlah nitrogen yang diserap oleh tanaman pada mulanya adalah sebesar $91,36 \mathrm{mg}(1,21 \%$ dari berat kering 7,55 gram) dan setelah 63 hari adalah sebesar $232,19 \mathrm{mg}(1,07 \%$ dari berat kering 21,7 gram).

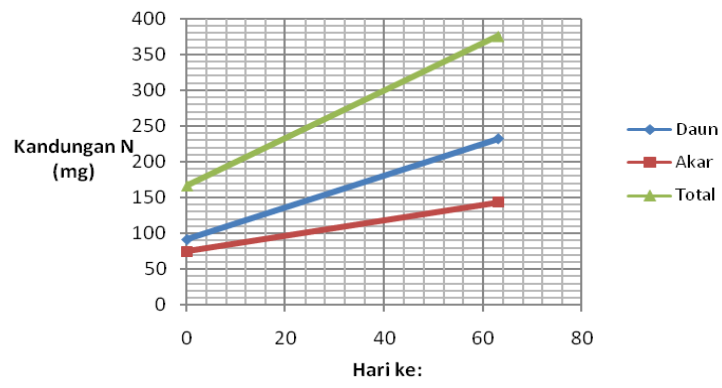

Gambar 6. Kandungan N pada Daun dan Akar Vetiver di Air Sungai 
Jumlah $\mathrm{P}$ yang diserap oleh tanaman di dalam kolam/bak air tanah (Gambar 7) pada mulanya adalah sebesar $3,78 \mathrm{mg}(0,05 \%$ dari berat kering 7,55 gram) dan setelah 63 hari adalah sebesar $1,24 \mathrm{mg}(0,02 \%$ dari berat kering 6,2 gram). Sedangkan jumlah fosfor yang diserap oleh tanaman di dalam kolam/bak air sungai (Gambar 8) pada mulanya adalah sebesar $3,78 \mathrm{mg}(0,05 \%$ dari berat kering 7,55 gram) dan setelah 63 hari adalah sebesar 4,34 $\mathrm{mg}(0,02 \%$ dari berat kering 21,70 gram $)$.

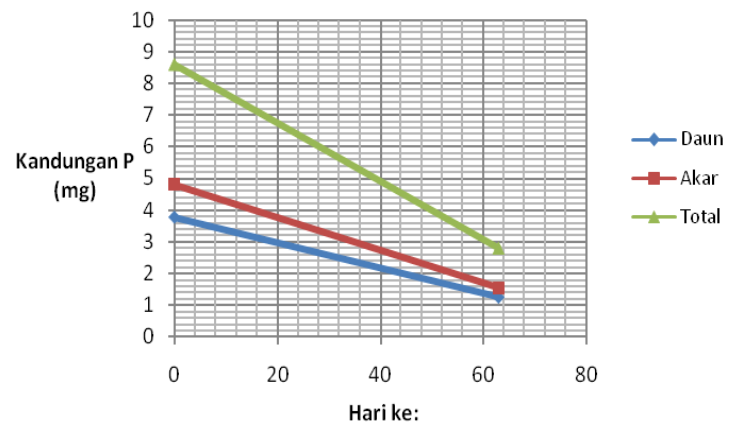

Gambar 7. Kandungan P pada Daun dan Akar Vetiver di Air Tanah

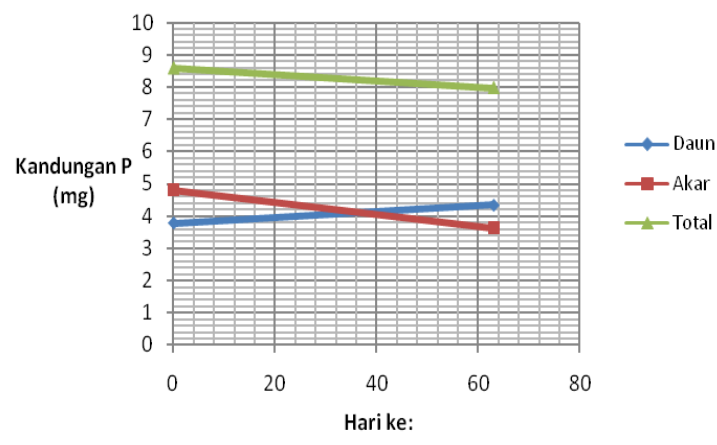

Gambar 8. Kandungan P pada Daun dan Akar Vetiver di Air Sungai

Jumlah C yang diserap oleh tanaman di dalam kolam/bak air tanah (Gambar 9) pada mulanya adalah sebesar $2.793,8 \mathrm{mg}$ (37\% dari berat kering 7,55 gram) dan setelah 63 hari adalah sebesar $2461,4 \mathrm{mg}(39,7 \%$ dari berat kering 6,2 gram). Sedangkan jumlah karbon yang diserap oleh tanaman di dalam kolam/bak air sungai (Gambar 10) pada mulanya adalah sebesar $2.793,8 \mathrm{mg}$ (37\% dari berat kering 7,55 gram) dan setelah 63 hari adalah sebesar $9.396,1 \mathrm{mg}$ (43,3\% dari berat kering 21,7 gram).

Melihat data tersebut agak sulit untuk menginterpretasikan berapa besar kemampuan tanaman untuk menyerap $\mathrm{N}$ dan $\mathrm{P}$ karena jumlah $\mathrm{N}$ dan $\mathrm{P}$ yang terdapat dalam media tumbuh kurang bisa dikatakan cukup atau sufficient, sebagaimana dikemukakan oleh Scheffe, bahwa pada tanaman jagung jumlah $\mathrm{N}$ dalam silase jagung dapat dinyatakan berkecupanan bila nilainya adalah 2,7-3,5 persen dan kondisinya difficient bila kurang dari 2,7 persen ${ }^{(12)}$. Melihat persentase yang ditampilkan dalam data pengukuran ternyata kandungan $\mathrm{N}$ dalam media tumbuh sangat kurang karena berada jauh di bawah nilai 2,7 persen.

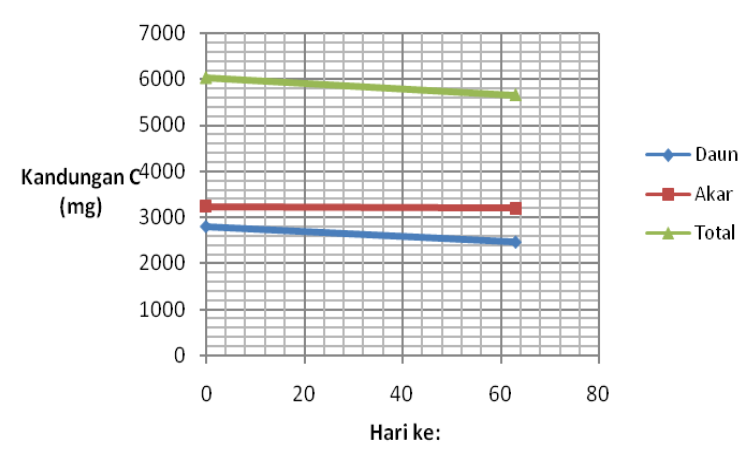

Gambar 9. Kandungan C pada Daun dan Akar Vetiver di Air Tanah

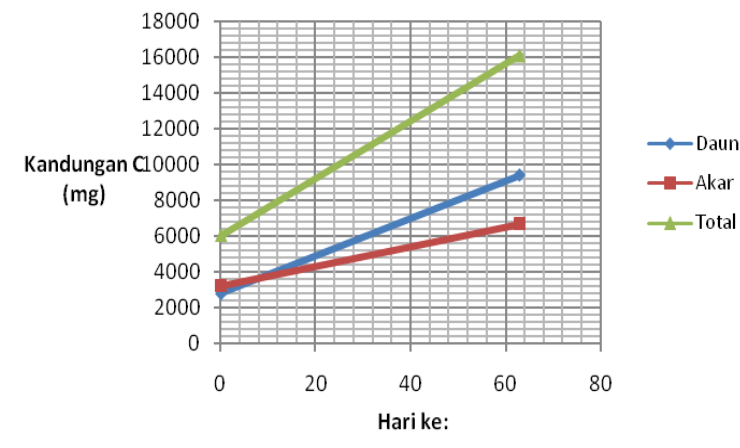

Gambar 10. Kandungan C pada Daun dan Akar Vetiver di Air sungai

Di sisi lain, mekanisme ini sangat baik untuk diterapkan dalam aplikasi teknologi fitoremediasi di kawasan bantaran sungai, karena selain untuk mengurangi konsentrasi nutrien dari pencemaran air sungai, mekanisme menambah panjang akar yang ditunjukkan oleh vetiver berarti kemampuan vetiver dalam mengurangi resiko tanah longsor dan erosi pada lahan bantaran sungai sangat baik. Hasil analisis jaringan akar menunjukkan bahwa jumlah nitrogen yang diserap oleh vetiver di dalam kolam/bak air tanah pada mulanya adalah sebesar $75,03 \mathrm{mg}$ dan menjadi $51,04 \mathrm{mg}$ setelah 63 hari masa tanam. Sedangkan analisis jaringan akar pada vetiver yang ditanam pada air tanah pada hari ke-0 adalah $75,03 \mathrm{mg}$ $(0,78 \%$ dari berat kering 9,62 gram $)$ dan menjadi $143,25 \mathrm{mg}(0,79 \%$ dari berat kering $18,13 \mathrm{gram})$ pada hari ke-63. 
Jumlah $\mathrm{P}$ yang terkandung pada jaringan akar vetiver yang ditanam pada media dengan sumber air tanah menunjukkan angka 4,81 $\mathrm{mg}$ $(0,05 \%$ dari berat kering 9,62 gram $)$ pada hari ke-0 dan $3,63 \mathrm{mg}(0,02 \%$ dari berat kering 18,13 gram) pada hari ke-63. Sedangkan jumlah $\mathrm{P}$ pada akar vetiver yang ditanam pada media air sungai menunjukkan angka $4,81 \mathrm{mg}$ pada hari ke-0 dan 1,55 mg pada hari ke-63.

Jumlah $\mathrm{C}$ yang terkandung pada jaringan akar vetiver yang ditanam pada media dengan sumber air tanah menunjukkan angka 3241,51 mg (33,7 \% dari berat kering 9,62 gram) pada hari ke-0 dan $3.193,87 \mathrm{mg}(41,3 \%$ dari berat kering 7,73 gram) pada hari ke-63. Sedangkan jumlah $\mathrm{C}$ yang terkandung pada jaringan akar vetiver yang ditanam pada dengan sumber air sungai menunjukkan angka $3.241,51 \mathrm{mg}(33,7$ $\%$ dari berat kering 9,62 gram) pada hari ke-0 dan $6.691,2 \mathrm{mg}(36,9 \%$ dari berat kering 18,13 gram) pada hari ke-63.

Teknik fitoremediasi ini telah diintroduksikan dibeberapa negara, seperti Tahiland, China, Filpina dan Australia, sebagai negara tetangga dalam upaya melestarikan lingkungannya ${ }^{(13,14)}$. Bahkan aplikasi di Indonesia, seperti di perairan sungai di Papua Barat ${ }^{(15)}$ dan Sungai Citarum di Jawa Barat ${ }^{(14,16)}$, telah diaplikasikan dalam upaya perbaikan kualitas air dan penguatan bantaran sungai.

Dengan menelaah data hasil analisa laboratorium terlihat pertumbuhan tanaman di media air sungai cukup signifikan selama kurun waktu 63 hari. Peningkatan kandungan bahan organik sebanyak hampir 3 kali lipat bahan organik awal menunjukkan hasil asimilasi dan perkembangan jaringan tanaman yang sangat signifikan.

\section{KESIMPULAN}

Beberapa kesimpulan yang dapat diambil pada kegiatan penelitian ini adalah, bahwa: tanaman vetiver menunjukkan pertumbuhan yang sangat baik pada media pertumbuhan dengan air sungai dibandingkan dengan air tanah. Artinya, vetiver dapat memanfaatkan nutrisi yang berasal dari air sungai (yang telah tercemar) dengan baik. Hal ini mengindikasikan bahwa vetiver dapat dijadikan tanaman unggulan dalam upaya mengurangi pencemaran air Sungai Cikapundung. Rumput vetiver sebagai rumput berkarakter hiper-akumulator, selain berperan dalam mengurangi konsentrasi pencemaran di perairan Sungai Cikapundung, pertumbuhan akar vetiver yang sangat cepat juga berarti tanaman ini dapat dimanfaatkan sebagai pencegah longsor dan erosi kawasan bantaran sungai.

\section{PERSANTUNAN.}

Ucapan terima kasih penulis sampaikan kepada teman Sejawat dan petugas teknis lapang, khususnya kepada Bapak Sabaruddin Wagiman Tjokrokusumo, lbu Rahmania Admirasari yang telah mendukung persiapan, pelaksanaan penelitian dan sampai terwujudnya tulisan ini.

\section{DAFTAR PUSTAKA}

1. Hidayat, (2003), Kualitas Air Sungai Cikapundung dan Teknologi Perbaikan yang Diperlukan, Seminar Nasional Sistem Monitoring Pencemaran Lingkungan Sungai dan Teknologi Pengolahannya, 7-8 Juli 2003, Pusat Penelitian Elektronika dan Telekomunikasi LIPI, Bandung.

2. Wardhani, E., B. Machbub, M.R. Sururi dan Salahudin, (2010), Inventarisasi Beban Pencemar BOD Air Sungai Citarum di Wilayah Kabupaten Bandung, Prosiding Seminar Tjipto Utomo 2010, Institut Teknologi Nasional, Hal.: B1-1-B1-10.

3. Pilon-Smits E., (2005), Phytoremediation, Annual Review Plant Biology, Vol. 56 : 1539.

4. Zheng, C., T. Cong, and C. Huairnan, (1997), Preliminary Study on Purification of Eutrophic Water with Vetiver, International Vetiver Grass Technology Workshop in Fuzhou, China, Tersedia di http://www.vetiver.org/CHN_Water\%20purific ation.htm, (dilihat October 1997).

5. Ash, R., and P. Truong, (2003), The Use of Vetiver Grass Wetlands for Sewerage Treatment in Australia, The Vetiver Network Award Winner.

6. Truong, P., T.T. Van, and E. Pinners, (2008), Vetiver Grass - The Plant., The Vetiver System, Vietnam 2000 - 2008.

7. Truong, P.N., and B. Hart, (2001), Vetiver System For Wastewater Treatment, Technical Bulletin No. 2001/2, Pacific Rim Vetiver Network, Royal Development Projects Board, Bangkok, Thailand.

8. Truong P., and L. Loch, (2004), Vetiver System For Erosion And Sediment Control, (Paper to be Presented at the $13 \mathrm{Th}$ International Soil Conservation Organisation Conference, Brisbane, 4-7 July 2004).

9. Anonim., (2001), Peraturan Pemerintah Republik Indonesia No. 82 Tahun 2000, tentang Pengelolaan Kualitas Air dan Pengendalian Pencemaran Air.

10. Anonim., (2009), Teknologi Pengelolaan Kualitas Air. Program Alih Jenjang D4 
Bidang Akuakultur SITH, ITB-VEDCASEAMOLEC.

11. LiYu, X. and Z. Jing, (2006), An Overview of The Use of Vegetation in Bioengineering, Tersedia di http://www.vetiver.org/ENG_biochina.htm.

12. Scheffe, L. (2008), Benefits of Conservation Tillage, Section 10a., Integrated Cropping Systems and Water Management Handbook (AGRO-76), USDA Natural Resources Conservation Service.

13. Truong $P$ and D.J. Booth, (2010), Report On The Application Of Vetiver System In The Citarum River Basin, Indonesia, Indonesian Vetiver Network and TVNI responsible for Asia and Oceania, Brisbane, Australia.
14. Truong, P., T.T. Van, E. Pinners, and D. Booth, (2011). Sistem Vetiver: Solusi yang Telah Terbukti dan Ramah Lingkungan, Diterbitkan oleh The Indonesian Vetiver Network.

15. Jeni, (2015), Minimalisasi Pencemaran Sungai Melalui Pengenalan Pemanfaatan Rumput Vetiver pada Masyarakat Sekitar Bantaran Sungai, FMIPA Universitas Negeri Papua, Jl. Gunung Salju Manokwari (Doi: 10.13140/Rg.2.1.1470.4083), Tersedia di http://www.researchgate.net/publication/283 854351.

16. Truong, P., (2011), Global review on The Application of Vetiver System for Infrastructure Protection, International Seminar on The Green Road Construction, Bandung, IRE-Agency for Research and Development, Ministry of Public Works. 